\section{Demography of Canada}

According to the report recently made to the International Office of Public Health (Bull. Off. internat. d'hyg. publ., 31, 1678; 1939) by Dr. H. B. Jeffs, the delegate for Canada, the population of Canada, exclusive of Yukon and the North Western Territories, amounted to about $11,106,000$ on June 1, 1937. The marriage-rate for 1937 was $7 \cdot 9$ per 1,000 inhabitants. The highest percentage of marriages was registered in Manitoba $(8 \cdot 5)$ and the lowest in Saskatchewan $(6 \cdot 2)$. The birth-rate was $19 \cdot 8$ per 1,000 inhabitants as compared with $20 \cdot 0$ in 1936 . The total number of live births was 219,988 in 1937 , as compared with $220,37 \mathrm{I}$ in the previous year. The highest birth-rate was in the province of Quebec, where 75,635 births were registered or a rate of $24 \cdot 1$ per thousand inhabitants. In 1937, 113,694 deaths were registered in Canada or a mortality of $10 \cdot 2$ per 1,000 inhabitants, as compared with $9 \cdot 7$ in 1936 . The total number of deaths of children under one year of age was 16,675 or a mortality of 76 per 1,000 live births as compared with 66 in 1936. The maternal mortality was 1,067 in 1937 or a mortality of 4.9 per 1,000 live births, as compared with 1,233 deaths or a rate of $5 \cdot 6$ in 1936. The highest maternal mortality was in Prince Edward Island (5.8 per 1,000 live births) and the lowest in Nova Scotia $(2 \cdot 7$ per 1,000 live births).

\section{A New Biological Journal}

UNDER the title of Lloydia the Lloyd Library of Natural History, Cincinnati, Ohio, has commenced the publication of a new quarterly journal of which the first number appeared as Vol. 1, Nos. 1-4, 1938 ; the date of publication is given as January 7, 1939, but a copy has only just reached Nature. The subscription rate is three dollars per annum. The editor is Theodor Just. From the numbers already published, the main field of the new journal would seem to be systematic, but papers dealing mainly with structure have been published and many of the communications have been freely illustrated with both drawings and photographs. Manuscript contributions are welcomed, as also exchanges with other institutions. Communications should be addressed to the Librarian, Lloyd Library, 309 W. Court Street, Cincinnati, Ohio.

\section{Bibliography of Seismology}

THE Bibliography of Seismology, 13, No. 2, published by the Dominion Observatory at Ottawa, has just been received. It contains 124 items over the period April, May, June 1939, and has been compiled with the assistance of collaborators in Canada, United States, New Zealand, Italy, Germany, Norway, Japan, U.S.S.R., France, Holland and England. As in the preceding number, in addition to works on pure seismology, there is again a considerable number of works listed on applied seismology, chiefly concerned with geophysical prospecting. A list of patents concerned with this latter contains eight items, five being United States patents, one Canadian, and two U.S.S.R. It is pleasing to see a considerable number of papers listed from the Seismological Institute, Academy of Sciences, U.S.S.R., though it would add to the value of these Russian works if the authors supplied translations. or abstracts in French, German or English. Unfortunately, again South America is not represented.

\section{Earthquake in Central America}

AN earthquake of considerable intensity was experienced on the Pacific coast of central America on December 5 just after 8.30 G.M.T., though no damage has been reported. The shock was recorded on practically all the seismographs in America; at De Bilt (Holland), where the preliminary waves arrived just after 8.42 ; and at Kew, where a full complement of waves including $P_{c} P, S K S$ and $S S S$ were readily discernible. The maximum ground displacement at Kew was $0.043 \mathrm{~mm}$. From readings of seismograms at adjacent stations, the epicentre has been determined by the United States Coast and Geodetic Survey to have been in the Pacific Ocean some twenty miles due east of Rio Suchiate (Guatemala).

\section{Announcements}

The U.S.S.R. Academy of Sciences has marked the sixtieth birthday of M. Joseph Stalin by electing him an honorary member of the Academy, nominally in recognition of his contributions to the development of the social theories of Marx and Lenin. It should be noted that even the ordinary membership of the Academy is restricted to a limited number of men of science of outstanding repute, while there are very few honorary members, all of them hitherto being scientific men of international fame.

Prof. Fritz Lejeune, of Cologne, has been appointed professor of the history of medicine and director of the Institute of the History of Medicine at Vienna.

THE Italian Minister of the Interior has offered a prize of 30,000 lire for the discovery of chemical or biological substances to take the place of insulin.

THE League of Nations Health Committee has arranged to set up a sub-committee which may be summoned in an emergency to deal with epidemics of infectious diseases arising out of the War.

THE Ministry of Health has published a memorandum on typhoid fever for the use of local authorities and medical officers of health (Memo. 225/Med. H.M. Stationery Office. 2d. net). The memorandum deals with typhoid and paratyphoid fevers, their history, diagnosis, prevention and control, and it contains an appendix on laboratory methods of diagnosis. 